\title{
Publisher Correction: Coherent modulation of the sea-level annual cycle in the United States by Atlantic Rossby waves
}

\author{
Francisco M. Calafat (10 ${ }^{1}$, Thomas Wahl ${ }^{2}$, Fredrik Lindsten ${ }^{3}$, Joanne Williams ${ }^{1}$ \& Eleanor Frajka-Williams ${ }^{4}$
}

Correction to: Nature Communications https://doi.org/10.1038/s41467-018-04898-y; published online 3 July 2018.

The original version of this Article contained an error in the first sentence in the legend of Fig. 1, which incorrectly read 'The first letter of 'Hatteras' should be capitalized, in both Figure $1 \mathrm{a}$ and $1 \mathrm{~b}$ since Hatteras is a proper noun.' The correct version removes this sentence. This has been corrected in both the PDF and HTML versions of the article.

Published online: 12 October 2018

\begin{abstract}
(c) (i) Open Access This article is licensed under a Creative Commons Attribution 4.0 International License, which permits use, sharing, adaptation, distribution and reproduction in any medium or format, as long as you give appropriate credit to the original author(s) and the source, provide a link to the Creative Commons license, and indicate if changes were made. The images or other third party material in this article are included in the article's Creative Commons license, unless indicated otherwise in a credit line to the material. If material is not included in the article's Creative Commons license and your intended use is not permitted by statutory regulation or exceeds the permitted use, you will need to obtain permission directly from the copyright holder. To view a copy of this license, visit http://creativecommons.org/licenses/by/4.0/.
\end{abstract}

(c) The Author(s) 2018

\footnotetext{
${ }^{1}$ National Oceanography Centre, Joseph Proudman Building, 6 Brownlow Street, L3 5DA Liverpool, UK. ${ }^{2}$ Department of Civil, Environmental and Construction Engineering and National Center for Integrated Coastal Research, University of Central Florida, 12800 Pegasus Drive, Suite 211, Orlando, FL, USA. ${ }^{3}$ Department of Information Technology, Uppsala University, Lägerhyddsv. 2, hus 2, 752 37, Uppsala, Sweden. ${ }^{4}$ Ocean and Earth Sciences, University of Southampton, European Way, SO14 3ZH Southampton, UK. Correspondence and requests for materials should be addressed to

F.M.C. (email: francisco.calafat@noc.ac.uk)
} 